This item was submitted to Loughborough's Research Repository by the author.

Items in Figshare are protected by copyright, with all rights reserved, unless otherwise indicated.

\title{
Health and safety management in developing countries: a study of construction SMEs in Ghana
}

PLEASE CITE THE PUBLISHED VERSION

PUBLISHER

(C) Taylor \& Francis

VERSION

AM (Accepted Manuscript)

LICENCE

CC BY-NC-ND 4.0

\section{REPOSITORY RECORD}

Kheni, Nongiba A., Andrew R.J. Dainty, and Alistair G.F. Gibb. 2019. "Health and Safety Management in Developing Countries: A Study of Construction Smes in Ghana". figshare. https://hdl.handle.net/2134/5942. 
This item was submitted to Loughborough's Institutional Repository (https://dspace.lboro.ac.uk/) by the author and is made available under the following Creative Commons Licence conditions.

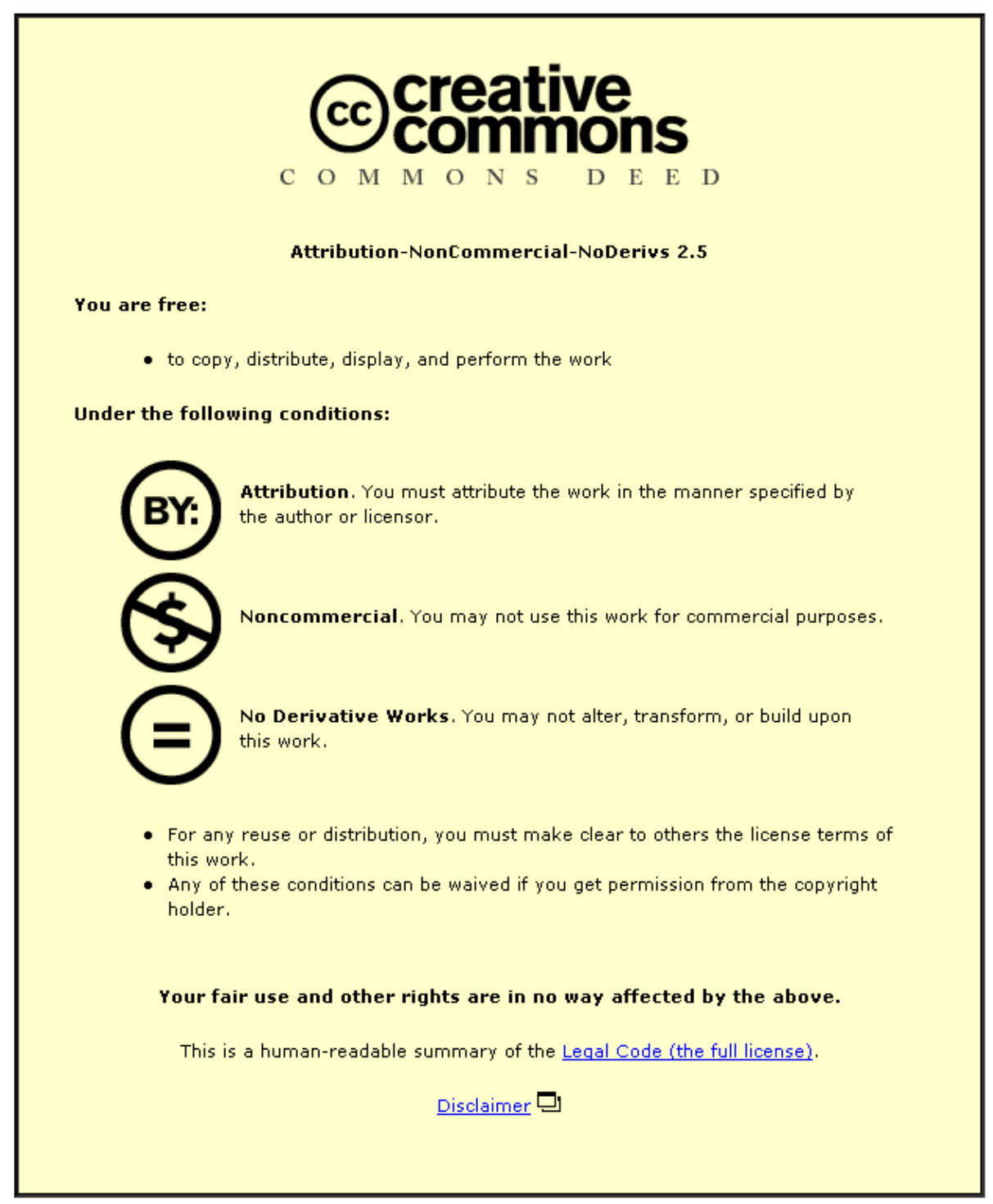

For the full text of this licence, please go to: http://creativecommons.org/licenses/by-nc-nd/2.5/ 


\title{
HEALTH AND SAFETY MANAGEMENT IN DEVELOPING COUNTRIES:
}

\section{A STUDY OF CONSTRUCTION SMEs IN GHANA}

Kheni, N; Gibb, A.G.F. \& Dainty, A.R.J., Health and safety management in developing countries: a study of construction SMEs in Ghana, Construction Management \& Economics, 2008, Vol 26, No 11, pp 1159-1169, ISSN 0144-6193 - online ISSN 1466-433X

\begin{abstract}
The construction industry plays a significant role in the economy of developing countries. The sector is, however, also one of the most hazardous with frequent accidents and health related problems. The purpose of this study is to examine the health and safety practices of construction small and medium-sized businesses (SMEs) in Ghana with a view to improving the health and safety performance of the sector. A survey questionnaire was administered to owner/managers of SMEs, with a response rate of $32 \%$ of the sampling frame obtained. The findings reveal that few of the SMEs adopted proactive health and safety practices. However, health and safety practices identified as being particularly associated with firm characteristics were: accident investigation procedures; accident reporting procedures; use of health and safety posters; documentation of method statements; and, health and safety inductions. The paper brings to light the diversity of health and safety practices associated with different size categories of SMEs and constraints to improving health and safety. Based on the analysis, recommendations aimed at a positive change in the attitudes of owner/managers which takes into account size-related constraints are suggested for improving the health and safety performance of Ghanaian SMEs.
\end{abstract}

Keywords: Construction health and safety; Developing countries; SMEs; survey.

\section{INTRODUCTION}


Construction is a hazardous industry whether in developed or developing countries and contributes to significant numbers of occupational accidents and ill health globally (Takala 1999). While developed nations have demonstrated commitment to achieving a reduction in accident numbers in industrial settings, the same cannot be said of developing countries, particularly Sub-Saharan Africa (SSA). Accident rates in these developing economies are unacceptably high and it is predicted that the numbers will increase in parallel with the pace of industrialisation (Hämäläinen et al. 2006). Many construction businesses operating in market economies have embraced a zero accident policy as their goal and implemented effective health and safety practices (Hinze and Wilson 2000). The attention paid to the construction industry and the risks posed by its activities has contributed to these achievements. However, despite the significance of the industry in developing countries, policy makers pay very little attention to it (Anaman and Osei-Amponsah, 2007).

The institutional and legal governance frameworks on occupational health and safety in developing countries have little impact (LaDou 2003). The majority of contractors are SMEs operating within their domestic markets where enforcement of health and safety standards and labour standards is very lax. Enforcement of health and safety regulations remains a problem due to lack of adequate resources available to government institutions responsible for occupational and safety administration. For example, Clarke (2005) has revealed the limited resources available to enforcement agencies and prevention services as the main factor contributing to poor health and safety conditions at Ghanaian workplaces. Also, there remains an acute need for contract provisions to support the enforcement of labour laws in developing countries (Cotton et al., 2005). These problems are compounded by shortages of skilled labour 
and qualified staff which confronts the industry in both developing and developed countries (Dainty et al. 2004; Mitullah and Wachira 2003). These factors combine to make the construction industry in developing countries unsafe.

In Ghana, the construction industry accounts for the highest rate of occupational deaths compared with other industrial sectors. According to the Labour Department (2000: 22), out of a total of 902 occupational accidents that occurred in construction in the year 2000, 56 were fatal, a fatality rate of 77.6 per 100000 workers. To put this into context, the European Union (EU) accident statistics (European Commission 2002) reveal that there are only 1.5 fatalities per 1000 accidents. The figures for developing countries look even worse when it is considered that many non-fatal accidents in the construction sector go unreported (Colak et al. 2004).

This paper reports on research which examined the health and safety practices of Ghanaian SME building contractors. The aim was to reveal the factors which might contribute to accidents within these firms and to identify possible policy measures which could mitigate the prevalence of accidents within the sector.

\section{BACKGROUND AND CONTEXT}

\section{Overview of construction health and safety management}

In response to tightening regulations and the need for effective and efficient management of health and safety, health and safety management systems have developed as a means of controlling the risks of hazards at workplaces. Dawson 
(1988) reported that the construction sector of Great Britain has responded slowly to adoption of health and safety management systems. Health and safety management systems are based on Deming's Plan-Do-Check-Act (PDCA) model of continuous quality improvement (Hamid et al. 2004). They may be mandatory or voluntary. Examples of occupational health and safety management systems include those contained within the Health and Safety Executive's (HSE) guidance on successful health and safety management (Health and Safety Executive 1997), British Standard BS 8800:2004, and the Occupational Health and Safety Assessment series OHSAS 18001.

A further development of occupational health and safety management systems is their integration with other management functions. Integration of safety function with other management functions such as quality and environment is argued to result in improved business performance (Alwani-Starr 1998; Davis 1998; Dias 1998). Gibb and Ayoade (1996) identified client pressure, cost reduction measures, total project management, and legislation as factors promoting the adoption of integrated safety management systems. In addition, advocates of integrated safety management systems have cited management effectiveness as an important factor justifying their use in construction (Douglas and Glen 2000; Hamid et al. 2004).

\section{Health and safety within SMEs}

Research has shown that small and medium-sized businesses (SMEs) face difficulties in implementing formal systems (Dawson et al. 1988; Eakin et al. 2000; Mayhew 2000). Informal management styles, lean management structures, and absence of bureaucratic procedures that form key characteristics of SMEs all militate against the formal and transparent processes required by health and safety management systems, and few examples of simplified health and safety management systems exist (Argrilla 1999; Helledi 1999). 
Definition of SMEs vary from one country or industrial sector to another. The Bolton committee (Bolton 1971) categorised construction firms with 25 employees as small although it also considered market share, management style and level of autonomy in deciding on the broad qualitative characteristics of SMEs. Comparability of results and the validation of the findings of research adopting similar definitions guided the choice of a definition suitable to the particular research problem in this study.

Eyiah and Cook (2003) note that Ghanaian contractors belonging to financial classes 2, 3 and 4 posses similar characteristics and could be regarded as SMEs. This definition has disadvantages. Firstly, the definition limits comparability of research results on SMEs since many definitions employ number of employees. Secondly, financial classifications are subject to review by government institutions that institute them. Thirdly, definitions of financial class employed by the Ministry of Road Transport (MRT) and Ministry of Works and Housing (MWH) differ on the minimum amount for each financial category. Thus a contractor regarded as class 3 by the former ministry may belong to a different financial class under the latter ministry’s classification scheme.

According to Addo-Abedi (1999), domestic construction businesses in Ghana operate within the domestic construction market and are managed as family businesses, rarely employing more than 200 employees. Thus, they may conveniently be regarded as SMEs based on the similar characteristics they possess. This study therefore defines SMEs as family run domestic contractors with the following thresholds relating to medium, small and micro construction businesses: 
- $\quad$ an upper threshold of 199 employees and a lower threshold of 30 employees are adopted for medium-sized construction businesses;

- $\quad$ small businesses are ones which employ 10-29 persons; and

- micro businesses are construction businesses whose number of employees does not exceed 9.

\section{Health and safety management practices of construction SMEs}

Literature on health and safety management provides evidence that there is varied implementation of health and safety standards in SMEs because of particular characteristics they possess. A survey conducted by Baldock et al., (2005) revealed marked variations in firms' health and safety practices. Internal factors found in the study which influenced the businesses' decisions to improve health and safety included; size (number of employees and turnover), growth performance, management experience and number of years the business has been operating. A study by Champoux and Brun (2003) also suggests small business characteristics are associated with health and management within SMEs. Areas of operation have also been found to relate to adoption of health and safety management practices; even were businesses operate in the same industry there can be marked variation in their health and safety practices depending on the nature of their product or service they render. For example, Birchall and Finlayson (1996) found that civil engineering contractors and building contractors differ markedly in their health and safety measures.

The body of research examining health and safety management practices of construction SMEs has focused on the external influences. For example Koehn et al. 
(1995) pointed out that some of the factors preventing contractors from implementing effective health and safety management practices or programmes include bureaucracy, workers' unawareness in relation to their rights and time pressures. Koehn et al. (2000) have stressed difficulties in training due to illiteracy as a barrier to effective health and safety management in developing countries. In a similar study, Gibb and Bust (2006) indicated that bad construction practices, extreme weather conditions, and disenabling socio-economic environment have a negative influence on health and safety management of construction sites in developing countries.

\section{Aims of the research project}

It follows from the preceding discussion that there are two major sets of influences on SMEs' health and safety under-performance; internal processes and externally imposed regulation. This study focuses on internal influences on health and safety management within SMEs. The study examined the implementation of health and safety practices and their associations with organisational characteristics of SMEs in the construction sector of Ghana, with a view to determining whether there are any significant associations between firms’ organisational characteristics and health and safety management practices. The characteristics considered included age of business, turnover, number of employees, and type of construction work the SMEs specialised in. Four hypotheses were developed based on the preceding literature:

Hypothesis (H) 1: the number of employees of construction SMEs is positively associated with their adoption of measures to control health and safety risks. 
Hypothesis (H) 2: the annual turnovers of construction SMEs is positively associated their adoption of health and safety measures to control health and safety risks on sites.

Hypothesis (H) 3: the adoption of health and safety measures by construction SMEs is associated with the type of construction works they are registered to undertake that is, whether they operate as civil engineering contractors or building contractors.

Hypothesis (H) 4: the number of years an SME has been operating is positively associated with the adoption of health and safety measures.

\section{METHOD}

\section{Questionnaire development}

A draft of the questionnaires was discussed with health and safety experts and the updated version piloted in the field setting with fifteen SMEs chosen from one region of the country different from the study regions. The final questionnaire developed and used in the study comprised questions with fixed response categories (dichotomous, and multiple choice) and open-ended questions. The questionnaires were divided into two sections. The first section requested personal information on respondents such as experience, position of respondent, and characteristics of respondents' businesses such as telephone number(s), address, type of work the business undertakes, number of employees, year of establishment of the business, the type of contractor classification the business had, and turnover. The responses to questions in the section therefore supplied the organisational characteristics of the 
firms namely; turnover (measured as annual turnover of the business in 2005), number of full time employees, age of the business (number of years the business has been operating), experience of respondent (number of years the respondent has been with the business) and type of contractor registration (civil engineering or building) which were the independent variables considered in the study.

A second section elicited response on the health and safety management practices of the owner/manager's business. For example, respondents were asked; “in your opinion, how well do your procedures meet the requirements of the following? (please tick)". The list of health and safety regulations and general conditions of contract that contractors are required to comply with supplied together with the options; completely, in part, not at all and do not know. The dependent variables in the study were 34 health and safety practices (refer to appendix A) which the respondents were asked to indicate whether they implemented or not. All thirty-four variables were listed under the question: "we are interested in knowing the processes you have in place for managing health and safety. Please indicate by ticking the relevant cells if you carry out the procedures stated below”. This question required a 'yes' or 'no'. Clearly such a question should be treated with caution given that some SMEs may tend to project a positive image of their businesses by claiming to implement practices which they do not actually carry out or rarely carry out. Practices which formed part of the Ghana conditions of contract (where quantities form part of the contract) were not considered in this study as proactive practices, while those which are not part of are proactive practices. The section also contained open-ended questions on constraints the businesses face in the management of health 
and safety and suggestions for improving health and safety measures on construction sites.

\section{Respondent sample}

The Ghanaian construction sector comprises both informal and formal sectors. The informal sector is made up self-employed individuals and communal organisations and are under-represented in contractors' associations in Ghana. Possible sampling frames available include contractors' registers of the relevant government ministries responsible for the registration of contractors and contractors' associations. However, lists of contractors compiled by government ministries are often not updated (Eyiah and Cook 2003). Their use as a sampling frame is therefore not recommended. Contractors' associations provide a more up to date sampling frame than the MRT and MWH lists and thus formed the sampling frame for the study.

A cluster sampling technique was adopted for the study. Three regions were randomly selected from the ten regions of the country and questionnaires together with postage-paid-addressed envelopes were sent to all the construction SMEs belonging to contractors' associations in the selected regions. The total number of questionnaires distributed was 1394. The selected regions represent a broad range of economic activity in the country (one region with the highest economy activity, the second with moderate economic activity and the third, the lowest economic activity).

\section{Procedure for analysing results}

The data was compiled using Epidata and subsequently read into SPSS. Late respondents were compared with early respondents using t-test to determine if there 
was non-response bias (the former being considered as surrogate non-respondents). Exploratory analysis of the data was carried out using the frequencies and descriptives commands of SPSS which enabled responses to be categorised and summarised. The procedure adopted for analysing the associations involved two stages; first a bivariate chi-square comparisons of the variables to identify significant associations between variables. Significant associations between variables found by this procedure were further analysed in the second stage. The method of analysis in the second stage employed binary logistic regression techniques based on the method's suitability for analysing a mix of categorical and continuous variables, while including no assumptions about the nature of their distributions (Cox and Snell 1989; Meyers et al. 2006).

The Chi-square test was used to compare thirty-four health and safety management variables describing health and safety practices of the businesses with five descriptive variables corresponding to definable characteristics of the businesses. The Chi-square test was used to test the hypotheses that row and column variables were independent at a significance level of 0.05 . The dependent variables in the study were dichotomous (binary) yes or no and the independent variables were measured at the scale or ratio level. This made it possible to use the binary logistic regression technique as explained in the preceding paragraph. The dependent variables in this research is defined as $\mathrm{Y}=1$ (implementation of health and safety practice) and $\mathrm{Y}=0$ (non implementation of health and safety practice). $\mathrm{X}$ denotes organisational characteristics. The binary logistic regression is stated as the probability of $\mathrm{Y}=1$ given $\mathrm{X}$.

$$
P(Y=1 / X)=\frac{1}{1+\operatorname{Exp}(-\beta X)}
$$


The linear predictor is defined as $\beta X$ and stands for $\beta_{0}+\beta_{1} X_{1}+$ $+\beta_{P} X_{P}$

The minimum recommended sample size is 30 times the number of parameters being estimated (Pedhazur 1997).

\section{RESULTS}

\section{Profile of the respondents and characteristics of the businesses}

A response rate of $32 \%$ was obtained with $28 \%$ of respondents belonging to micro businesses, 55\% were small businesses, and 17\% were medium-sized businesses. Table 1 summarises the distribution of the SME categories in the sample, the proportion of the different categories in the sample that responded and the distribution of size in the population of SMEs registered nationally with the Association of Road contractors (ASROC) for which statistics on the different size categories is available. The percentage of responses from small and medium SMEs are approximately equal and relatively higher than the percentage of micro businesses that responded. This bias towards larger sizes suggests a difference in attitudes between the micro businesses and the other SME categories to responding to questionnaires. A comparison of the responses with the size distribution of the population of SMEs registered with ASROC also shows the apparent under representation of micro businesses in the responses received. Thus, findings of the study need to be interpreted with caution in the light of this bias in response.

“Insert Table 1 here” 
Slightly more than half of the respondents were managing directors with the rest being either managers (29\%) or other senior management personnel (10\%). Over 80 per cent of the respondents had over 15 years experience. The responses to the questions could therefore be considered as true and accurate reflections of the businesses in view of the positions and years of experience of the respondents. In Ghana, many construction businesses are registered as building contractors. This was reflected in the responses received; 68 per cent building contractors and 47 per cent road contractors. About 15 per cent of the businesses registered as both building and road contractors.

\section{Compliance with health and safety regulations}

The majority of the businesses were found to rely solely on health and safety procedures in contracts (Table 2). When asked how well their procedures met the provisions in contract conditions and relevant health and safety law, almost all stated that their procedures met health and safety provisions in contract conditions. This response should be treated with caution as not many businesses would admit that they are unable to meet their contractual obligations. Forty-nine per cent indicated that their procedures met the Labour Act, and a quarter of them indicated that their procedures partly met the Factories, Offices, and Shops Act. Sixteen per cent of the respondents registered their sites as required under the Factories, Offices, and Shops Act. The most frequent reason cited by respondents for not registering their sites was that they considered their sites too small to warrant registration with the Factories Inspectorate Department. When asked to which department they reported their accidents, only 7 per cent indicated that they reported their accidents to the Factory Inspectorate Department and 60 per cent said they reported to the Labour Department. Given that contractors in Ghana are required to submit a labour certificate which gives an indication that they comply with labour laws of the country, the relatively high response of reporting to the Labour Department is 
unsurprising. The responses on Workmen's Compensation Act with regard to their health and safety procedures indicated that less than a quarter of the SMEs had implemented procedures that met the Act. Again, this response must be treated with caution given that many businesses may not admit that they pay no regard to laws that border on their operations.

“Insert Table 2 here”

\section{Health and safety procedures}

When asked about their health and safety procedures, over three quarters of the respondents indicated that they had instituted measures such as first aid, provision of drinking water, personal protective equipment, obtaining labour certificate for their labour, site inspections, and provision of cloak and toilet facilities on site (Table 3). These procedures were often stipulated in most contract conditions which may explain why so many of the businesses adopted the practices. The results on proactive health and safety measures suggest relatively fewer SMEs implement measures other than those provided for in contract conditions. These health and safety procedures adopted by the businesses included: accident reporting (48\%); rewards for safe behaviour (43\%); documentation of method statements (27\%); hazard identification (32\%); health and safety consultants (21\%); inductions (19\%); asking workers of their ideas on health and safety (22\%); using health and safety posters (27\%); and accident investigations (19\%). Site safety inspections were informal and very common (83\%).

“Insert Table 3 here” 


\section{Regression results}

The results of the chi-square test indicated statistically significant relationships between organisational characteristics and 21 health and safety practices. These relationships merited further investigation using binary logistic regression. Table 4 presents the regression coefficients (B), the Wald statistics, significance level, odds ratio $(\operatorname{Exp}(B))$, and 95\% confidence interval (C.I.) for odd ratios for each independent variable significantly associated with a health and safety practice.

“Insert Table 4 here”

\section{DISCUSSION}

\section{Regression results}

Annual turnover is positively associated with five health and safety practices adopted by the SMEs namely; accident investigation procedures, accident reporting procedures, use of health and safety posters, documentation of method statements, and health and safety inductions. The binary regression coefficients positively correlate with the values of annual turnover categories that are significantly associated with all five health and safety practices. While no causality can be claimed to exist between turnover and these five health and safety practices, the results suggest that the null hypothesis, that there is no association between the health safety practices of SMEs and turnover, can be rejected.

The regression coefficients for the binary logistic analysis on the number of full-time employees suggest that number of full-time employees is positively associated with four health and safety practices including accident investigation procedures, accident 
reporting procedures, use of health and safety posters, and health and safety inductions. The regression coefficient for health and safety documentation is negative and therefore worth commenting on. If all organisational characteristics were controlled for, the coefficient becomes positive, indicating the existence of a similar correlational effect. These results suggest that the null hypothesis, that there is no association between the adoption of health and safety practices by the SMEs and the number of full-time employees can be rejected.

The preceding findings lend some support to the hypothesis that turnover and number of employees are positively associated with implementation of health and safety practices (hypotheses 1 and 2). This result supports assertions of a positive association between organisational characteristics and health and safety management practices in SMEs (e.g. Champoux and Brun 2003). However, the practices considered here are health and safety practices often excluded from contract provisions, and so may be regarded proactive health and safety management. SMEs operate under similar constraints particularly lack of resources as identified by the aforementioned study. For example, Commercial banks in Ghana are unlikely to consider applications for loans from smaller size categories because of the risk associated with such businesses making it difficult to manage business functions including health and safety effectively. The results also accord with Baldock et al.'s (2005) finding that larger, more established and growth-oriented small firms are likely to take health and safety improvement decisions.

Contractors registered to carry out civil and road works or those registered to carry out building construction works is strongly associated with the documentation of 
method statements. These classifications exclude specialist contractors such as electrical contractors and mechanical installation contractors which have fewer number of SMEs in Ghana. Fewer SMEs that undertake building works document method statements compared with those that undertake civil engineering works. Civil and road projects in Ghana require a significant commitment of public funds and so public accountability is a driving factor for public officers involved in such expenditure to adopt more stringent measures. Generally therefore, proper project documentation and compliance with labour standards are more exacting on civil projects than building projects. The funding of civil infrastructure development in most countries in Sub-Saharan Africa (SSA) is provided by international donor agencies such as Department for International Development (DFID), International Development Agency (IDA), Danish Development Agency (DANIDA) and World Bank. These funding bodies have contributed to improving health and safety standards in civil and road sector of the construction industry through their involvement in the procurement process. These two factors could provide plausible explanations of the popularity of documentation of method statements among civil and road SMEs in the study compared with building contractors. This finding also accords with the literature which indicates that civil engineering contractors are better at implementing health and safety measures than building contractors (Birchall and Finlayson 1996). The results therefore support the third hypothesis of the study that the adoption of health and safety measures by construction SMEs is associated with the type of construction works they are registered to undertake that is, whether they operate as civil engineering contractors or building contractors. 
The regression results also indicate the age of SME is significantly associated with health and safety inductions. Older firms are likely to draw on experience gained over years to implement health and safety inductions and orientations on site. In regard, the hypothesis that the number of years an SME has been operating is positively associated with the adoption of health and safety measures is supported (Hypothesis 4).

\section{Health and safety management practices}

The results indicate that over half of the owner/managers were not sure if their procedures met health and safety provisions of Ghana's main health and safety legislation; the Factories, Offices and Shops Act. Accident reporting to the Factory Inspectorate Department is poor and many of the SMEs in the study rarely registered their sites as required under the Factories, Offices and Shops Act. Not surprisingly therefore, the number of respondents who indicated that they complied with the labour Act was more than the number that complied with the Factories, Offices, and Shops Act. The number of businesses reporting their accidents to the Factory Inspectorate Department was the smallest compared to other departments to which accidents were reported. This raises a serious concern given that the main body of construction health and safety regulation is contained in the Factories, Offices, and Shops Act. Ghana has few resources available for enforcing occupational health and safety regulation. As in 2006, there were 34 factory inspectors, 4 occupational health physicians and 1 occupational health nurse. Health and safety regulations cut across various ministries, departments, and agencies and the high level of bureaucracy is a barrier to inspectors carrying out their duties efficiently and effectively. The results contrast with research results of other developing countries. For instance Peckitt et 
al.'s (2002) study on health and safety in the Caribbean construction industry shows that directors and project managers were often ignorant of their duties under the health and safety legislation and health and safety legislation was rarely enforced.

Koehn et al. (1995) also indicated contractors and employers in India generally ignore basic health and safety regulations. Established safety procedures for managing health and safety risks were also not the norm. Privatisation of state owned enterprises in most Sub-Saharan African countries has had a tremendous influence on the construction industry. As Wells (2001) indicates, the formal construction process is gradually superseded by informal construction in these developing countries. Clients and contractors circumvent regulations and formal processes to get their finished building at a low cost. Unless there is stringent enforcement of health and safety regulations, little attention will be paid to health and safety in such industry environments since the contractors' prime objective is to maximise profits and that of small private clients which dominate the industry is to obtain the finished product at the lowest cost.

The owner/managers cited lack of resources, lack of commitment on the part of government, lack of guidance information on health and safety, shortage of skilled labour, competition, low levels of literacy, bad behaviours of employees and attitudes to health and safety as major constraints hindering effective health and safety management. A distinction needs to made between these constraints and those publicised in the general literature on health and safety management in SMEs (Mayhew 1995; Nichols 1997; Walters 2001). SMEs in developing countries face structural constraints due to the way work is organised. In most developing countries 
such as Ghana, the industry relies on procedures, regulations and practices which are legacies of colonial administration. Procedures have not been updated to reflect the social, cultural, and economic milieus of developing countries. The appropriateness of rules, procedures and regulations has long been questioned (Edmonds and Miles 1984; Wells 1986). A complete overhaul of procedures to reflect levels of industrialisation and social life of people in developing countries vis-à-vis health and safety is necessary.

\section{Limitations of the study}

The SMEs that participated in the study could differ in their opinion on health and safety issues by virtue of their affiliation with the contractors' associations. For instance, they could consider the potential benefits of the research to their associations. This factor could have induced socially desirable responses in addition to respondents conceiving of the research as a means to showcase their concern for the health and safety of their workers. There is therefore the likelihood that the level of health and safety activities/practices of, and responses given by the SMEs may be overstated in this study.

\section{Recommendations for improving health and safety}

The results of the study indicate few SMEs implement proactive health and safety measures to control the risks of hazards. Education and advertising are therefore needed to address the lack of awareness of health and safety standards required by legislation. Such campaigns could be organised by the appropriate ministries, departments, and agencies responsible for occupational health and health and safety and should target owner/managers. Possible sources of funding include Non- 
Governmental Organisations (NGOs) operating in developing countries, levying contractors and government sources.

To improve compliance with health and safety laws by SMEs, contracts need to be fair on the health and safety risks to be borne by contractors. It is recommended that the cost of implementing health and safety standards should also be identified within preliminaries and accommodated within prime cost items in bills of quantities.

The results suggest a gap in the implementation of health and safety practices between smaller size SME categories and larger ones as firm size is positively correlated with the adoption of health and safety management practices. To address this gap, it is recommended that future health and safety interventions discriminate between the different size bands of SMEs - that is micro, small, and medium-sized.

\section{CONCLUSIONS}

The study has revealed that owner/managers have little knowledge of the legal framework governing health and safety in the construction industry of Ghana, a finding which supports previous assertions as to the health and safety practices of construction firms in developing countries. The regression results revealed that implementation of health and safety practices by the SMEs is strongly correlated to organisational characteristics; as firm size (number of employees and turnover) increases so does the of adoption of proactive health and safety practices.

It would appear that institutional constraints severely hinder the management of health and safety in Ghana. An enabling policy environment is also lacking. From the 
point of health and safety, this impacts negatively on the activities of contractors, clients, and various actors within the supply chain in the construction industry of developing countries. A comprehensive strategy which takes into consideration the policy environment, the institutional and legal frameworks, and the planning and execution processes is necessary to bring a step change in attitude to construction health and safety in the immediate future.

\section{REFERENCES}

Addo-Abedi, F. Y. (1999) Sustained development of the local contracting industry in a developing country. Proceedings of the Second International Conference on Construction Industry Development.

Alwani-Starr, G. M. (1998) Practical site management: Integration of health and safety, quality and environmental impact. Proceedings of the International Conference of CIB Working Commission W99, Lisbon, Portugal.

Anaman, K. A. and Osei-Amponsah, C. (2007) Analysis of the causality links between the growth of the construction industry and the growth of the macro-economy in Ghana. Construction Management and Economics, 25(7-9), 951-961.

Argrilla, J. A. (1999) Construction Safety Management Formula for Success. Proceedings of the Second International Conference of CIB Working Commission W99, Honolulu, Hawaii.

Baldock, R., Vickers, I., Smallbone, D., and James, P. (2005). Health and safety in small firms: what are the main influences on the adoption of improvement measures?, MUBS Discussion paper. 
Birchall, S. J., and Finlayson, H. (1996) The application of European Directive Safety Management Regulations to the British Construction Industry. Implementation of Safety and Health on Construction Sites CIB W99, Lisbon, 41-52.

Bolton, J. (1971). Small Firms; Report of the committee of inquiry on small firms. HMSO, London.

Champoux, D., and Brun, J.-P. (2003). Occupational health and safety management in small size enterprises: an overview of the situation and avenues for intervention and research. Safety Science, 41(4), 301-318.

Clarke, E. (2005). Do occupational health services really exist in Ghana? In: Challenges to Occupational Health Services in the Regions: The National and International Responses, Proceedings of a WHO/ICOH/ILO Workshop (edited by Lehtinen, S., Rantanen, J., Elgstrand, K., Liesivuori, J. \& Peurala, M.). Finish Institute of Occupational Health, Helsinki.

Coble, R. J., and Haupt, T. C. (1999) Construction Safety in Developing Countries. Proceedings of the Second International Conference of CIB Working Commission W99, Honolulu, Hawaii, 903-908.

Colak, B., Etiler, N. \& Bicer, U. 2004. Fatal occupational injuries in the construction sector in Kocaeli, Turkey, 1990-2001. Industrial Health 42, 424-430.

Cotton, A. P., Sohail, M., and Scott, R. E. (2005). Towards improved labour standards for construction of minor works in low income countries. Engineering, Construction and Architectural Management, 12(6), 617-632. 
Cox, D. R., and Snell, E. J. (1989). Analysis of Binary Data, Chapman and Hall, New York.

Dainty, A. R. J., Ison, S. G., and Root, D. S. (2004). Bridging the skills gap: A regionally driven strategy for resolving the construction labour market crisis. Engineering, Construction and Architectural Management, 11(4), 275-283.

Davis, K. (1998) Construction Quality and Safety -Similarities and Interaction. Proceedings of the International Conference of CIB Working Commission W99, Lisbon, Portugal.

Dawson, S., Willman, P., Bamford, M., and Clinton, A. (1988). Safety at work: The limits of self-regulation. Cambridge University Press, Cambridge, UK.

Dias, L. A. (1998) Integrating Environmental, Quality and Safety Management in Construction. Proceedings of the International Conference of CIB Working Commission W99, Lisbon, Portugal.

Douglas, A., and Glen, D. (2000). Integrated management systems in small and medium enterprises. Total Quality Management, 11(4/5\&6), 686-690.

Duff, A. R. (1998) Management and Operative Safety Improvement: A Goal for the Whole Organisation. Proceedings of the International Conference of CIB Working Commission W99, Lisbon, Portugal.

Eakin, J., Lamm, F., and Limborg, H. (2000) International perspective on the promotion of health and safety in small workplaces. Systematic OHS Management: Perspectives on an International Development, Amsterdam. 
Edmonds, G. A., and Miles, D. W. J. (1984). Foundations for Change: Aspects of the Construction Industry in Developing Countries, Intermediate Technology Publications Ltd, London, UK.

European Commission. 2002. European social statistics: accidents at work and workrelated health problems 1994-2000. European Communities, Luxembourg. Accessed from website on $18^{\text {th }}$ February 2008. http://ec.europa.eu/employment_social/health_safety/docs/social_statis tics_1994_2000_en.pdf

Eyiah, A. \& Cook, P. (2003). Financing small and medium-scale contractors in developing countries: A Ghana case study. Construction Management and Economics 21(4), 357-367.

Gibb, A., and Bust, P. (2006). Construction Health and Safety in Developing Countries, European Construction Institute, Great Britain, 77pp, ISBN 1873844638.

Gibb, A. G. F., and Ayoade, A. I. (1996) Integration of quality, safety and environmental systems. Implementation of Safety and Health on Construction Sites, Proceedings of the First International Conference of CIB Working Commission W99, Portugal, 11-20.

Hämäläinen, P., Takala, J., and Saarela, K. L. (2006). Global estimates of occupational accidents. Safety Science, 44, 137-156.

Hamid, A. R. A., Singh, B., Yusof, W. Z. W., and Yang, A. K. T. (2004). Integration of safety, health, environment and quality (SHEQ) management system in construction: a review. Jurnal kejuruteraan awam, 16(1), 24-37. 
Haslam, R. A., Hide, S. A., Gibb, A. G. F., Gyi, D. E., Atkinson, S., Pavitt, T. C., Duff, R., and Suraji, A. (2003). Causal factors in construction accidents. Health and Safety Executive HSE Report RR156 September 2003 22pp.

Health and Safety Executive. (1997). Successful health and safety management: HSG65, Health and Safety Executive, Sudbury, UK.

Helledi, U. (1999) Development and implementation of an occupational health and safety management system on construction sites-experiences from twelve small and medium-sized contractors. Proceedings of the Second International Conference of CIB Working Commission W99, Hawaii, 3-10.

Hinze, J., and Wilson, G. (2000). Moving toward a zero objective. Journal of Construction Engineering and Management, 126(5), 399-403.

Hong Kong Government. (1996). Works Branch Technical Circular: Pay for Safety Scheme (PFSS). Works Bureau, Hong Government Secretariat $4^{\text {th }}$ March 1996.

Koehn, E., Ahmed, S. A., and Jayanti, S. (2000) Variation in construction productivity: developing countries. AACE International Transactions, Morgantown, pg. 14A, 7 pgs.

Koehn, E., Kothari, R. K., and Pan, C.-S. (1995). Safety in developing countries: Professional and bureaucratic problems. Journal of Construction Engineering and Management, 121(3), 261-265.

Labour Department. (2000). Annual Report. Labour Department, Acccra, Ghana. LaDou, J. (2003). International occupational health. International Journal of Hygiene and Environmental Health 206, 1-11. 
Lingard, H., and Rowlinson, S. (1994). Construction site safety in Hong Kong. Construction Management and Economics, 12, 501-510.

Mattila, M., and Hyödynmaa, M. (1988). Promoting job safety in building: an experiment on the behaviour analysis approach. Journal of Occupational Accidents, 9, 255-267.

Mayhew, C. (1995). An evaluation of the Impact of Robens Style Legislation on the OHS Decision-making of Australian and United Kingdom Builders with less than Five Employees. Worksafe Australian Research Report, Sydney, Australia.

Mayhew, C. (2000). Occupational Health and Safety Issues for Young Workers in the Fast-food Industry, Sydney.

Meyers, L. S., Gamst, G., and Guarino, A. J. (2006). Applied Multivariate Research: Design and Interpretation, Sage Publications Ltd., London.

Mitullah, W. V., and Wachira, I. N. (2003). Informal labour in the construction industry in Kenya: A case study of Nairobi. International Labour Organisation, Geneva.

Nichols, T. (1997). The Sociology of Industrial Injury, Mansell, London.

Peckitt, S. J., Glendon, A. I., and Booth, R. T. (2002) A comparative study on safety in culture of the construction in Britain and Caribbean: Summary of the findings. Proceedings of the Triennial Conference CIB W099 Implementation of Safety and Health on Construction Sites, Hong Kong, 257-265.

Peckitt, S. J., Glendon, A. I., and Booth, R. T. (2004). Societal Influences on Safety Culture in the Construction Industry. Construction Safety Management Systems, S. Rowlinson, ed., Spon Press, London. 
Pedhazur, E. J. (1997). Multiple Regression in Behavioral Research: Explanation and Prediction, Harcourt Brace, Orlando, FL.

Smallwood, J. (2002) Health and Safety (H\&S) and Religion: Is there a Link? Proceedings of the Triennial Conference CIB W099 Implementation of Safety and Health on Construction Sites, Hong Kong.

Suraji, A., Duff, A. R., and Peckitt, S. J. (2001). Development of a causal model of construction accident causation. Journal of Construction Engineering and Management, 127(4), 337-344.

Takala, J. 1999. Global estimates of fatal occupational accidents. Epidemiology 10(5), 640-646.

Walters, D. (2001). Health and Safety in Small Enterprise. PIE Peter Lang, Oxford.

Wells, J. (1986). The Construction Industry in Developing Countries: Alternative Strategies for Development, Cromm Helm Ltd., London.

Wells, J. (2001). Construction and capital formation in less developed economies: unravelling the informal sector in an African city. Construction Management and Economics, 19, 267-274.

World Bank. 1984. The Construction Industry: Issues and Strategies in Developing Countries. World Bank, Washington D.C.

Table 1 Distribution of SMEs

\begin{tabular}{llll}
\hline SME size category & $\begin{array}{l}\text { Proportion of population } \\
\text { (ASROC) }\end{array}$ & Proportion of sample & $\begin{array}{l}\text { Proportion of sample } \\
\text { that responded }\end{array}$ \\
\hline Micro & $51 \%(335)$ & $46 \%(638)$ & $20 \%(125)$ \\
Small & $39 \%(256)$ & $42 \%(584)$ & $42 \%(245)$ \\
Medium & $10 \%(66)$ & $12 \%(172)$ & $44 \%(76)$ \\
Total & $100 \%(657)$ & $100 \%(1394)$ & $132 \%(446)$ \\
\hline
\end{tabular}


NB Figures in brackets are absolute figures

Table 2 How well the businesses' health and safety procedures met relevant health and safety regulations

\begin{tabular}{|c|c|c|c|c|c|c|c|c|}
\hline & \multicolumn{2}{|c|}{$\begin{array}{l}\text { Conditions of } \\
\text { contract }\end{array}$} & \multicolumn{2}{|c|}{ Labour Act } & \multicolumn{2}{|c|}{$\begin{array}{l}\text { Factories, Offices } \\
\text { and Shops Act }\end{array}$} & \multicolumn{2}{|c|}{$\begin{array}{l}\text { Workmen's } \\
\text { Compensation Act }\end{array}$} \\
\hline & Count & $\%$ & Count & $\%$ & Count & $\%$ & Count & $\%$ \\
\hline Completely & 440 & 98.7 & 198 & 44.4 & 46 & 10.4 & 68 & 15.3 \\
\hline In part & 1 & 0.2 & 220 & 49.3 & 112 & 25.1 & 138 & 30.9 \\
\hline Not at all & 0 & 0.0 & 16 & 3.6 & 14 & 3.1 & 211 & 47.3 \\
\hline Do not know & 5 & 1.1 & 12 & 2.7 & 274 & 61.4 & 29 & 6.5 \\
\hline Total & 446 & 100.0 & 446 & 100.0 & 446 & 100.0 & 446 & 100.0 \\
\hline
\end{tabular}

Table 3 Responses on health and safety practices which are often provisions in conditions of contract

\begin{tabular}{|c|c|c|c|c|}
\hline \multicolumn{5}{|l|}{ Health and safety measure } \\
\hline & Count & $\%$ & Count & $\%$ \\
\hline Provision of first aid & 33 & 8.2 & 371 & 91.8 \\
\hline PPE & 79 & 19.6 & 325 & 80.4 \\
\hline Provision of drinking water & 36 & 8.9 & 368 & 91.1 \\
\hline Labour certificate before commencing works & 54 & 13.4 & 350 & 86.6 \\
\hline Provision of cloak and toilet facilities & 96 & 23.8 & 308 & 76.2 \\
\hline
\end{tabular}


Table 4 Regression results

\begin{tabular}{|c|c|c|c|c|c|c|c|}
\hline \multirow[t]{2}{*}{$\begin{array}{l}\text { Step } 1 \\
\text { Variables }\end{array}$} & \multirow[t]{2}{*}{ B } & \multirow[t]{2}{*}{ Wald } & \multirow[t]{2}{*}{ df } & \multirow[t]{2}{*}{ Sig. } & \multirow[t]{2}{*}{$\operatorname{Exp}(B)$} & \multicolumn{2}{|c|}{$\begin{array}{l}\text { 95.0\% C.I.for } \\
\text { EXP(B) }\end{array}$} \\
\hline & & & & & & Lower & Upper \\
\hline \multicolumn{8}{|c|}{ Accident investigation procedures } \\
\hline Annual turnover (4) & 2.0 & 6.6 & 1 & 0.01 & 7.3 & 1.6 & 33.0 \\
\hline Full time employees & 0.1 & 15.9 & 1 & 0.00 & 1.1 & 1.0 & 1.1 \\
\hline Constant & -3.2 & 17.2 & 1 & 0.00 & 0.1 & & \\
\hline \multicolumn{8}{|c|}{ Accident reporting procedures } \\
\hline Annual turnover (5) & 1.9 & 9.1 & 1 & 0.00 & 7.0 & 2.0 & 24.6 \\
\hline Full time employees & 0.1 & 14.4 & 1 & 0.00 & 1.1 & 1.0 & 1.1 \\
\hline Constant & -2.5 & 15.8 & 1 & 0.00 & 0.1 & & \\
\hline \multicolumn{8}{|c|}{ Health and safety posters } \\
\hline Annual turnover (3) & 1.9 & 13.8 & 1 & 0.00 & 7.0 & 2.5 & 19.4 \\
\hline Full time employees & 0.1 & 10.4 & 1 & 0.00 & 1.1 & 1.0 & 1.1 \\
\hline Constant & -1.4 & 9.0 & 1 & 0.00 & 0.3 & & \\
\hline \multicolumn{8}{|c|}{ Health and safety rewards } \\
\hline Annual turnover (3) & 2.5 & 12.9 & 1 & 0.00 & 11.6 & 3.1 & 44.3 \\
\hline Full time employees & 0.1 & 9.7 & 1 & 0.00 & 1.0 & 1.0 & 1.1 \\
\hline Type of construction & 1.5 & 33.5 & 1 & 0.00 & 4.5 & 2.7 & 7.6 \\
\hline Constant & -2.6 & 16.5 & 1 & 0.00 & 0.1 & & \\
\hline \multicolumn{8}{|c|}{ Documentation of method statements } \\
\hline Annual turnover (2) & 4.4 & 11.1 & 1 & 0.00 & 78.6 & 6.1 & 1022.3 \\
\hline Full time employees & -0.1 & 11.5 & 1 & 0.00 & 1.1 & 1.0 & 1.1 \\
\hline Type of construction & 1.2 & 20.3 & 1 & 0.00 & 3.3 & 2.0 & 5.5 \\
\hline Constant & -2.6 & 12.5 & 1 & 0.00 & 0.1 & & \\
\hline \multicolumn{8}{|c|}{ Health and safety inductions } \\
\hline Annual turnover (3) & 1.8 & 8.1 & 1 & 0.00 & 5.8 & 1.7 & 19.30 \\
\hline Full time employees & 0.1 & 13.5 & 1 & 0.00 & 1.1 & 1.0 & 1.07 \\
\hline Age company & 0.1 & 21.0 & 1 & 0.00 & 1.1 & 1.0 & 1.11 \\
\hline Constant & -3.2 & 25.8 & 1 & 0.00 & 0.1 & & \\
\hline
\end{tabular}


Appendix A Health and safety practices used as dependent variables in the study

\begin{tabular}{|c|c|}
\hline \multicolumn{2}{|c|}{ Company commitment } \\
\hline Formal health and safety policy & $\begin{array}{l}\text { Procedures for investigating } \\
\text { accidents }\end{array}$ \\
\hline Designated safety person & Procedures for reporting accidents \\
\hline Using outside health and safety consultants & Provision of drinking water on site \\
\hline Provision of canteen service on site & $\begin{array}{l}\text { Provision of cloak and toilet } \\
\text { facilities on site }\end{array}$ \\
\hline Provision of first aid box & $\begin{array}{l}\text { Provision of personal protective } \\
\text { equipment }\end{array}$ \\
\hline \multicolumn{2}{|c|}{ Worker consultation and participation } \\
\hline $\begin{array}{l}\text { Our workers participate in hazard identification on } \\
\text { sites }\end{array}$ & $\begin{array}{l}\text { We consult trade union } \\
\text { representatives on health and safety }\end{array}$ \\
\hline $\begin{array}{l}\text { We reward workers who demonstrate exemplary } \\
\text { safe behaviour on site }\end{array}$ & $\begin{array}{l}\text { We ask workers for their ideas on } \\
\text { health and safety matters }\end{array}$ \\
\hline \multicolumn{2}{|c|}{ Communication } \\
\hline Using health and safety posters & $\begin{array}{l}\text { Networking with other } \\
\text { companies/institutions }\end{array}$ \\
\hline Discussing health and safety during site meetings & $\begin{array}{l}\text { Communicating health and safety } \\
\text { performance to employees }\end{array}$ \\
\hline $\begin{array}{l}\text { Verbal communication with operatives during site } \\
\text { tours }\end{array}$ & $\begin{array}{l}\text { Communicating health and safety } \\
\text { through company newsletter }\end{array}$ \\
\hline \multicolumn{2}{|c|}{ Health and safety planning } \\
\hline We obtain a labour certificate for every contract & Document method statements \\
\hline Document risk assessments & $\begin{array}{l}\text { Pricing health and safety in } \\
\text { preliminaries }\end{array}$ \\
\hline $\begin{array}{l}\text { Identification of hazards on sites before work } \\
\text { commences }\end{array}$ & $\begin{array}{l}\text { Disciplinary measures to correct } \\
\text { wrong behaviours relating to health }\end{array}$ \\
\hline Insurance cover for sites & $\begin{array}{l}\text { Ensuring adequate welfare } \\
\text { provisions on site }\end{array}$ \\
\hline \multicolumn{2}{|c|}{ Education and training } \\
\hline Site inductions for operatives & Toolbox talks \\
\hline $\begin{array}{l}\text { Planned health and safety training for supervisors } \\
\text { and/ or senior management }\end{array}$ & $\begin{array}{l}\text { Planned health and safety training of } \\
\text { operatives - first aid, manual lifting }\end{array}$ \\
\hline \multicolumn{2}{|c|}{ Monitoring and review } \\
\hline Setting health and safety performance targets & Carrying out site inspections \\
\hline
\end{tabular}

